\title{
KECERDASAN EMOSIONAL DAN COPING CAREGIVER PADA PASIEN STROKE HEMORAGIK DI RSUD SOEDIRAN MANGUN SUMARSO WONOGIRI
}

\author{
Kristna Adi Nugraha, Ros Endah Happy Patriyani \\ Kementerian Kesehatan Politeknik Kesehatan Surakarta Jurusan Keperawatan
}

\begin{abstract}
Caregiver, Coping, Emotional Intelligence. Stroke acute attack caused physical disability and mental disability. The state will required caregiver assistance. Stroke patients will require treatment time is long enough so that will make the caregiver feel bored and empathy will be reduced. Bored in a long time will cause disturbed emotional. The Purpose of Research to investigate the relationship between emotional intelligence and coping caregivers for patients with hemorrhagic stroke in RSUD Soediran Mangun Sumarso Wonogiri. This research used correlation description with cross-sectional. The Research Subject were caregivers for patients with hemorrhagic stroke in RSUD Soediran Mangun Sumarso Wonogiri. Research carried out for a month. Sampling technique used total sampling and obtained 68 respondents. Research instruments used questionnaries. The result of emotional intelligence $(73,5 \%)$ and coping $(82,4 \%)$ in a good result. Spearman Rho test showed relationship between emotional intelligence and coping, significance level 0,042 and corellation 0,247. Low relation between emotional intelligence with coping caregivers for patients with hemorrhagic stroke in RSUD Soediran Mangun Sumarso Wonogiri. The next research, expected to add variable about characteristics of caregiver that affect the emotional intelligence and coping.
\end{abstract}

Keywords : Caregiver, Coping, Emotional Intelligence.

Abstrak : Pengasuh, Penanganan, Kecerdasan Emosional. Pengasuh, Penanganan, Kecerdasan Emosional. Serangan akut stroke menyebabkan cacat fisik dan cacat mental. Negara akan membutuhkan bantuan pengasuh. Pasien stroke akan memerlukan waktu pengobatan yang cukup lama sehingga akan membuat pengasuh merasa bosan dan empati akan berkurang. Bosan dalam waktu lama akan menimbulkan gangguan emosional. Tujuan Penelitian untuk mengetahui hubungan antara kecerdasan emosional dan pengasuh asuhan penderita stroke hemoragik di RSUD Soediran Mangun Sumarso Wonogiri. Penelitian ini menggunakan deskripsi korelasi dengan cross-sectional. Subjek penelitian adalah perawat untuk penderita stroke hemoragik di RSUD Soediran Mangun Sumarso Wonogiri. Penelitian dilakukan selama sebulan. Teknik sampling menggunakan total sampling dan diperoleh 68 responden. Instrumen penelitian menggunakan kuesioner. Hasil kecerdasan emosional $(73,5 \%)$ dan coping $(82,4 \%)$ dalam hasil yang baik. Uji Spearman Rho menunjukkan hubungan antara kecerdasan emosional dan coping, tingkat signifikansi 0,042 dan corelasi 0,247. Rendahnya hubungan antara kecerdasan emosional dengan pengasuh asuh penderita stroke hemoragik di RSUD Soediran Mangun Sumarso Wonogiri. Penelitian selanjutnya, 
diharapkan dapat menambah variabel tentang karakteristik pengasuh yang mempengaruhi kecerdasan emosional dan penanganannya.

Kata Kunci : Pengasuh, Penanganan, Kecerdasan Emosional

\section{PENDAHULUAN}

Stroke merupakan masalah terbesar yang dihadapi hampir di seluruh dunia, baik di negara maju ataupun berkembang (Junaidi, 2004). Insidennya terus mengalami peningkatan. Kurang lebih 15 juta orang setiap tahun di seluruh dunia terserang stroke. Sebagian besar berada di negara berkembang, termasuk Indonesia. Stoke berada di urutan ketiga sebagai penyebab kematian di dunia setelah jantung dan kanker. Selain itu stroke juga merupakan penyebab kecacatan jangka panjang nomor satu di dunia. Data beberapa rumah sakit besar di Indonesia menunjukkan bahwa jumlah pasien stroke senantiasa meningkat. Diperkirakan hampir 50\% ranjang bangsal pasien saraf diisi oleh penderita stroke, yang didominasi oleh pasien dengan usia lebih dari 40 tahun. Hasil penelitian epidemologis juga menunjukkan bahwa resiko kematian pada 5 tahun pasca-stroke adalah $45-61 \%$ dan terjadi stroke berulang 25-37\% (Handayani, 2013).

Angka kejadian stroke menurut Riset Kesehatan Dasar tahun 2013 yaitu 12.1 dari 100 penduduk. Angka kejadian pada usia 15-24 tahun yaitu 0.2 dari 1000 penduduk. Pada usia 25-34 tahun yaitu 0.6 dari 1000 penduduk. Usia 33-44 tahun angka kejadiannya yaitu 10.4 dari 1000 penduduk. Usia 55-64 tahun yaitu 24 dari 1000 penduduk. Usia 65-74 tahun yaitu 33.2 dari 1000 penduduk. Untuk usia lebih dari 75 tahun yaitu 43.1 dari 1000 penduduk. Prevalensi pada laki-laki lebih tinggi daripada wanita yaitu 7.1 dari 1000 penduduk, sedangkan wanita 6.8 dari
1000 penduduk. Catatan dalam buku profil kesehatan Jawa Tengah tahun 2012 disebutkan bahwa 0.07 lebih tinggi dari tahun 2011 (0.03 \%). Angka kejadian stroke hemoragik di RSUD Soediran Mangun Sumarso Wonogiri pada tahun 2015 sebanyak 206 pasien pada rawat inap dan 98 pada pasien rawat jalan.

Serangan stroke yang akut menyebabkan kecacatan fisik, dan mental. Keadaan tersebut akan memerlukan bantuan orang lain (caregiver). Penderita stroke akan memerlukan perawatan yang cukup lama. Waktu yang cukup lama ini akan membuat caregiver merasa bosan dan mungkin rasa empatinya akan berkurang. Kejenuhan yang cukup lama akan menyebabkan keadaan emosionalnya akan terganggu. Pada keadaan inilah diperlukan suatu sikap untuk mengenali emosi, mengelola emosi, memotivasi diri sendiri, mengenali emosi orang lain dan membina hubungan dengan orang lain. Beberapa sikap tersebut akan membantu caregiver mengatasi terjadinya perubahan emosi. Respon manusia atau dalam hal ini caregiver terhadap stres, selalu berhubungan dengan respon coping dan reaksi emosi yang buruk (Safaria, 2009).

Kecerdasan emosional seseorang akan menuntut seseorang mengenali emosi, mengelola emosi, memotivasi diri sendiri, mengenali emosi orang lain atau empati, dan membina hubungan. Hal penting dalam pembinaan hubungan adalah kemampuan untuk memahami emosi orang lain dan kemudian bertindak bijaksana berdasarkan pemahaman tersebut. Kemampuan untuk 
mengekspresikan emosi secara tepat kepada orang lain juga merupakan hal penting dalam membina hubungan. Memotivasi diri sendiri merupakan kemampuan menata emosi diri sendiri yang digunakan sebagai alat pencapaian tujuan (Goleman, 2001).

Kemampuan dalam mengenali emosi pada diri seseorang akan mempengaruhi seseorang untuk melakukan apapun. Seseorang yang merawat pasien yang cukup lama akan meningkatkan tekanan psikologi dalam diri seorang caregiver. Caregiver akan melakukan usaha untuk menguasai, meredakan, ataupun menghilangkan tekanan psikologis. Tiap persoalan akan membutuhkan coping yang berbeda. Kejenuhan dapat membuat coping (mekanisme pertahanan diri) seseorang caregiver akan membuat perubahan jenis coping yang sebelumnya bersifat adaptif akan menjadi maladaptif. Ketidakmampuan seseorang dalam menggunakan strategi coping yang efektif menunjukkan rendahnya kemampuan coping orang tersebut.

Penulis telah melakukan studi pendahuluan yang dilakukan pada 10 caregiver pasien stroke didapatkan data bahwa 7 dari 10 caregiver mempunyai kecerdasan emosional yang baik. 6 dari 7 yang mempunyai kecerdasan emosional yang baik juga menggunakan coping yang bersifat problem focused coping dan sisanya ternyata menggunakan emotion focused coping. Lama caregiver merawat mempengaruhi kecerdasan emosional dan coping caregiver. Berdasarkan studi pendahuluan tersebut diperlukan adanya penelitian tentang hubungan kecerdasan emosional dan coping caregiver pada pasien stroke haemoragik. Selama ini belum pernah penelitian tentang hubungan kecerdasan emosional dan coping caregiver pada pasien stroke haemoragik di RSUD Soediran Mangun Soemarso Wonogiri.

Berdasarkan uraian di atas maka penulis tertarik melakukan penelitian tentang hubungan kecerdasan emosional dan coping caregiver pada pasien stroke haemoragik di RSUD Soediran Mangun Soemarso Wonogiri

\section{METODE PENELITIAN}

Jenis penelitian ini merupakan penelitian kuantitatif non-ekperimental. Rancangan penelitian yang digunakan adalah deskripsi korelasi dengan pendekatan cross-sectional. Populasi dalam penelitian ini adalah seluruh caregiver pada pasien stroke hemoragik di RSUD Soediran Mangun Sumarso Wonogiri dalam kurun waktu satu bulan dengan jumlah populasi sebanyak 70 orang. Dari 70 caregiver yang sesuai dengan kriteria inklusi dan eksklusi adalah sebanyak 68 responden.

\section{HASIL PENELITIAN}

1. Univariat

Tabel 1

Distribusi Frekuensi Caregiver Pada

Pasien Stroke Hemoragik di RSUD

Soediran Mangun Sumarso Wonogiri Berdasarkan Jenis Kelamin

\begin{tabular}{|c|c|c|}
\hline $\begin{array}{c}\text { Jenis } \\
\text { Kelamin }\end{array}$ & Frekuensi & Persentase \\
\hline Laki-Laki & 28 & 41,2 \\
\hline Perempuan & 40 & 58,8 \\
\hline Total & 68 & 100,0 \\
\hline
\end{tabular}
terbanyak berjenis kelamin perempuan sebanyak 40 responden $(58.8 \%)$. 
Tabel 2

Distribusi Frekuensi Caregiver Pada

Pasien Stroke Hemoragik di RSUD

Soediran Mangun Sumarso Wonogiri Berdasarkan Usia

\begin{tabular}{|c|c|c|}
\hline Usia & Frekuensi & Persentase \\
\hline Remaja & 8 & 11,8 \\
\hline Dewasa & 50 & 73,5 \\
\hline Lansia & 10 & 14,7 \\
\hline Total & 68 & 100,0 \\
\hline
\end{tabular}

terbanyak berusia dewasa sebanyak 50 responden $(73,5 \%)$.

Tabel 3

Distribusi Frekuensi Caregiver Pada

Pasien Stroke Hemoragik di RSUD

Soediran Mangun Sumarso Wonogiri

Berdasarkan Status Perkawinan

\begin{tabular}{ccc}
\hline $\begin{array}{c}\text { Status } \\
\text { Perkawinan }\end{array}$ & Frekuensi & Persentase \\
\hline Tidak kawin & 7 & 10,3 \\
Kawin & 61 & 89,7 \\
\hline Total & 68 & 100,0 \\
\hline
\end{tabular}

Berdasarkan tabel 43 responden

terbanyak sudah menikah sebanyak 61 responden $(89,7 \%)$.

Tabel 4

Distribusi Frekuensi Caregiver Pada

Pasien Stroke Hemoragik di RSUD

Soediran Mangun Sumarso Wonogiri

Berdasarkan Pendidikan Terakhir

\begin{tabular}{ccc}
\hline $\begin{array}{c}\text { Tingkat } \\
\text { Pendidikan }\end{array}$ & Frekuensi & Persentase \\
\hline Rendah & 6 & 8,8 \\
Sedang & 48 & 70,6 \\
Tinggi & 14 & 20,6 \\
\hline Total & 68 & 100,0 \\
\hline
\end{tabular}

Berdasarkan tabel 4 tingkat pendidikan responden terbanyak adalah sedang sebanyak 48 responden $(70,6 \%)$. Tingkat pendidikan sedang dalam penelitian ini adalah SMA/ sederajat.
Tabel 5

Distribusi Frekuensi Caregiver Pada

Pasien Stroke Hemoragik di RSUD

Soediran Mangun Sumarso Wonogiri Berdasarkan Status Pekerjaan

\begin{tabular}{|c|c|c|}
\hline $\begin{array}{c}\text { Status } \\
\text { Pekerjaan }\end{array}$ & Frekuensi & Persentase \\
\hline Tidak & 14 & 20,6 \\
\hline Bekerja & & \\
\hline Bekerja & 54 & 79,4 \\
\hline Total & 68 & 100,0 \\
\hline
\end{tabular}
terbanyak telah mempunyai pekerjaan yaitu sebanyak 54 responden $(79,4 \%)$.

Tabel 6

Distribusi Frekuensi Caregiver Pada Pasien Pasien Stroke Hemoragik Bedasarkan Lama Caregiver Merawat Pasien.

\begin{tabular}{|c|c|c|}
\hline $\begin{array}{c}\text { Lama } \\
\text { Merawat } \\
\text { Pasien }\end{array}$ & Frekuensi & Persentase \\
\hline $\begin{array}{c}6-12 \\
\text { bulan }\end{array}$ & 55 & 80,9 \\
\hline $\begin{array}{l}13-36 \\
\text { bulan }\end{array}$ & 11 & 16,2 \\
\hline $\begin{array}{l}\text { Lebih dari } \\
36 \text { bulan }\end{array}$ & 2 & 2,9 \\
\hline Total & 68 & 100,0 \\
\hline
\end{tabular}
telah merawat pasien terbanyak selama 612 bulan yaitu 55 responden $(80,9 \%)$.

\section{Tabel 7}

Distribusi Frekuensi Caregiver Pada

Pasien Stroke Hemoragik di RSUD

Soediran Mangun Sumarso Wonogiri Bardasarkan Hubungan antara Caregiver dengan Pasien

\begin{tabular}{ccc}
\hline $\begin{array}{c}\text { Hubungan } \\
\text { dengan } \\
\text { Pasien }\end{array}$ & Frekuensi & Persentase \\
\hline Suami & 4 & 5,9 \\
Istri & 13 & 19,1 \\
Anak & 51 & 75,0 \\
\hline Total & 68 & 100,0 \\
\hline
\end{tabular}


Berdasarkan tabel 7 responden yang merawat pasien adalah anak sebanyak 51 responden $(75 \%)$.

\section{Tabel 8}

Distribusi Frekuensi Caregiver pada Pasien Stroke Hemoragik di RSUD Soediran Mangun Sumarso Wonogiri Berdasarkan Kecerdasan Emosional

\begin{tabular}{ccc}
\hline $\begin{array}{c}\text { Kecerdasan } \\
\text { Emosional }\end{array}$ & Frekuensi & Presentase \\
\hline Baik & 50 & 73,5 \\
Kurang & 18 & 26,5 \\
\hline Total & 68 & 100,0 \\
\hline
\end{tabular}

Berdasarkan tabel 8 responden mempunyai kecerdasan emosional baik yaitu 50 responden $(73,5 \%)$.

\section{Tabel 9}

Distribusi Frekuensi Caregiver pada Pasien Stroke Hemoragik di RSUD Soediran Mangun Sumarso Wonogiri Berdasarkan Coping

\begin{tabular}{ccc}
\hline Coping & Frekuensi & Persentase \\
\hline Baik & 56 & 82,4 \\
Kurang & 12 & 17,6 \\
\hline Total & 68 & 100,0 \\
\hline
\end{tabular}

Berdasarkan tabel 9 responden mempunyai coping yang baik yaitu 56 responden $(82,6 \%)$.

\section{Bivariat}

Uji hubungan antara kecerdasan emosional dan coping caregiver pada pasien stroke hemoragik yang digunakan dalam penelitian ini adalah Spearman's rho.

Tabel 10

Hasil uji hubungan antara kecerdasan emosional dan coping caregiver pada pasien stroke hemoragik.

\begin{tabular}{lcc}
\hline \multicolumn{1}{c}{ Variabel } & Korelasi & P \\
\hline Kecerdasan & & \\
Emosional & 0,247 & 0,042 \\
\hline Coping & & \\
\hline
\end{tabular}

Berdasarkan tabel 10 diketahui bahwa signifikansi pada Spearman's Rho adalah $\mathrm{p}<0,05$, maka dapat disimpulkan bahwa ada hubungan antara kecerdasan emosional dan coping caregiver pada pasien stroke hemoragik. Berdasarkan nilai korelasi yang didapatkan yaitu 0,247 berarti menandakan hubungan yang terjadi berkorelasi rendah. Berdasarkan hasil uji didapatkan semakin baik kecerdasan emosiol semakin baik coping.

\section{PEMBAHASAN}

Berdasarkan hasil penelitian, caregiver yang telah merawat lebih dari 6 bulan mempunyai kecerdasan emosional dalam kategori baik. Didukung dengan Penelitian Bagus Iswoyo (2015) dan Ridwan Saptoto (2010) kecerdasan emosional yang baik akan dimiliki apabila mereka tahu dengan benar perasaannya, mereka dapat menjelaskan dengan tepat keadaan emosinya kepada orang lain, mereka sadar akan perubahan dalam suasana hatinya, mereka mampu mengenali dirinya sendiri ketika mulai frustasi atau marah, mereka peka terhadap perasaannya, mereka memperhatikan keadaan pikirannya dengan kata-kata, suasana hati mereka akan mudah dipahami, mereka tidak bingung dengan yang mereka rasakan, mereka tahu akan alasan emosinya, suasana hati mereka konsisten, dan mereka meluangkan banyak waktu untuk berusaha. Hal ini menunjukkan berarti caregiver telah memenuhi aspek-aspek kecerdasan emosional. Sesuai dengan teori Daniel Goleman (2001) aspek-aspek dalam kecerdasan emosi adalah mengenali emosi pribadinya, mengelola emosi, memotivasi dan memberikan dorongan untuk maju kepada diri sendiri, mengenal emosi dan 
kepribadian orang lain, dan membina hubungan dengan pihak lain secara baik.

Berdasarkan hasil penelitian kemampuan coping caregiver dalam kondisi baik. Hal tersebut menunjukkan bahwa caregiver mempunyai strategi koping yang baik dapat berupa emotionalfocused coping dan problem-focused coping. Caregiver telah mampu mengubah kondisi yang stress menjadi terkendali. Individu dapat menghadapi stressor dengan baik tergantung pada strategi coping yang digunakan. Pernyataan tersebut didukung pendapat Rasmun (2004) bahwa strategi yang digunakan efektif sehingga menghasilkan adaptasi yang baik.

Pada penelitian didapatkan data bahwa 70,6 \% pendidikan caregiver berpendidikan sedang (SMA) sehingga memiliki kecerdasan emosional dan coping yang baik. Pendidikan yang juga mempengaruhi yaitu pendidikan tinggi yaitu sarjana dan diploma dengan jumlah responden $14(20,6 \%)$. Taraf pendidikan akan berpengaruh dalam kecerdasan emosional karena akan mempengaruhi pola pikir seseorang terhadap sesuatu hal atau dalam hal ini tentang kecerdasan emosional. Didukung dengan pernyataan Shapiro (dalam Indriani, 2007) pendidikan dapat menjadi salah satu wahana belajar individu dalam mengembangkan kecerdasan emosi. Lebih lanjut dijelaskan oleh Shapiro, melalui pendidikan individu mulai dikenalkan dengan berbagai bentuk kemampuan emosi, baik yang berkenaan dengan dirinya maupun dengan orang lain dan lingkungan sekitar.

Pada penelitian ini usia terbanyak adalah dewasa. Usia akan mempengaruhi kecerdasan emosional dan mekanisme coping seseorang. Pernyataan tersebut sesuai teori dari Lukman (2009) usia mempengaruhi daya tangkap dan pola pikir seseorang. Semakin bertambahnya umur akan diikuti bertambahnya daya tangkap dan pola pikir seseorang.

Berdasarkan hasil penelitian menyebutkan bahwa ada hubungan antara kecerdasan emosional dan coping caregiver pada pasien stroke hemoragik di RSUD Soediran Mangun Sumarso Wonogiri. Hasil tersebut diperkuat dengan penelitian yang dilakukan oleh Ridwan Saptoto (2010) yang menyatakan bahwa ada hubungan antara kecerdasan emosional dan kemampuan coping adaptif.

Berdasarkan hasil penelitian dapat diambil pernyataan bahwa kecerdasan emosional yang baik akan mempunyai coping yang baik juga. Hal tersebut didukung Bagus Iswoyo (2015) dalam penelitiannya menyebutkan bahwa kecerdasan emosional dapat digunakan dalam pengambilan keputusan. Kecerdasan emosional yang baik pada seseorang akan mempengaruhi seseorang untuk memilih mekanisme coping.

Hasil penelitian menunjukkan bahwa care giver dengan kecerdasan emosional yang baik dan coping yang baik lebih cenderung tidak mudah terbawa emosi negatif, dan tidak mudah terpancing terhadap hal-hal yang negatif. Hal tersebut memenyebabkan care giver lebih sabar dalam merawat pasien stroke hemoragik. Pernyataan tersebut didukung dengan penelitian Bagus Iswoyo (2015) yang menyebutkan bahwa kecerdasan emosional berguna dalam penyesuaian diri dan membina hubungan yang baik dengan orang lain. Hal tersebut tersebut sesuai dengan teori yang dikemukakan Rahmawati (2007) yaitu mereka yang mempunyai kecerdasan emosional yang baik akan mengambil keputusan dan 
melakukan tindakan yang tepat saat situasi ktitis dan mendesak.

\section{KESIMPULAN DAN SARAN}

Berdasarkan penelitian yang telah dilakukan dapat diambil kesimpulan sebagai berikut:

1. Karakteristik caregiver pada pasien stroke hemoragik di RSUD Soediran Mangun Sumarso Wonogiri terdiri dari jenis kelamin terbanyak perempuan $(58,8 \%)$, usia terbanyak dewasa $(73,5 \%)$, status perkawinan terbanyak telah menikah $(89,7 \%)$, tingkat pendidikan terbanyak sedang $(70,6 \%)$, status pekerjaan terbanyak bekerja $(79,4 \%)$, lama merawat pasien terbanyak 6-12 bulan (80,9\%), dan hubungan caregiver dengan pasien terbanyak adalah anak $(75 \%)$.

2. Kecerdasan emosional caregiver pada pasien stroke hemoragik di RSUD Soediran Mangun Sumarso Wonogiri dalam keadaan baik $(73,5 \%)$.

3. Coping caregiver pada pasien stroke hemoragik di RSUD Soediran Mangun Sumarso Wonogiri dalam keadaan baik $(82,4 \%)$.

4. Adanya hubungan antara kecerdasan emosional dengan coping caregiver pada pasien stroke hemoragik di RSUD Soediran Mangun Sumarso Wonogiri dengan taraf signifikansi 0,042 dan korelasi 0,247.

Setelah melakukan penelitian ini peneliti mempunyai saran, sebagai berikut:

1. Selama ini belum pernah dilakukan pendidikan kesehatan tentang pengelolaan kecerdasan emosional dan coping di RSUD Soediran Mangun Sumarso Wonogiri. Oleh karena itu, perawat diharapkan dapat memberikan pendidikan kesehatan kepada caregiver tentang pengelolaan kecerdasan emosional dan coping agar meningkatkan kemampuan caregiver dalam mengelola hal tersebut.

2. Bagi penelitian selanjutnya diharapkan menggunakan pendekatan cross-sectional dengan disertai observasi atau pengamatan pada saat caregiver merawat pasien agar data yang diambil dalam keadaan yang sebenarnya. Peneliti menyarankan untuk menambahkan variabel karakteristik caregiver (jenis kelamin, usia, status perkawinan, tingkat pendidikan, status pekerjaan, lama merawat pasien, dan hubungan caregiver dengan pasien) yang mempengaruhi kecerdasan emosional dan coping.

\section{DAFTAR RUJUKAN}

Goleman. (2001). Emotional Intellegences: Kecerdasan Emosional. Mengapa EI Lebih Penting Dibanding IQ. Jakarta: PT. Gramedia

Handayani, Fitria. (2013). Angka kejadian Serangan Stroke Pada Wanita Lebih Rendah daripada Laki-Laki. Vol 1 (1). Jakarta: PT. Gramedia Pustaka Utama

Indriani, Y. (2007). "Hubungan Antara Kecerdasan Emosional dengan Kemampuan Memecahkan Masalah pada Siswa Kelas II SMU Piri I Yogyakarta". Skripsi: Universitas Ahmad Dahlan Yogyakarta

Iswoyo, Bagus. (2015). "Hubungan antara Kecerdasan Emosional dengan Mekanisme Koping pada 
Mahasiswa Tingkat I S-

1Keperawatan Tahun Ajaran

2014/2015 STIKES Hang Tuah

Surabaya". Jurnal

Junaidi, Iskandar. (2004). Panduan

Praktis Pencegahan dan

Pengobatan Stroke. Jakarta:

Bhuana Ilmu Populer Kelompok

Gramedia

Lukman. (2009). Ansietas Pada Fraktur. Jakarta: Salemba Medika

Rasmun. (2004). Stress, Koping, dan Adaptasi. Jakarta: CV. Segung Seto

Safaria, Triantoro. (2009). Manajemen emosi: Sebuah Panduan Cerdas Bagaimana Mengelola Emosi Positif dalam Hidup Anda; editor: Fatna Yustianti. -Ed. 1, Cet. 1.Jakarta: Bumi Aksara

Saptoto, Ridwan. (2010). "Hubungan Kecerdasan Emosi dan Coping Adaptif'. Jurnal Psikologi. 37 (1). 13-22.

Sugihantono, Anung (2013). Buku Profil Kesehatan Jawa Tengah 2012. Semarang: Dinas Kesehatan Jawa Tengah

Trihono. (2013). Riset Kesehatan Dasar 2013. Jakarta: Kementrian Kesehatan

Weuve, et al. (2000). "Caregiver Burden and The Geriatric Patient". Journal of Gerontologist. 40 (4). 429-36 